\title{
NEW WORLD BASQUE TOPONYMY IN THE DIALOGUE OF LANGUAGES AND CULTURES
}

\author{
OLGA CHESNOKOVA ${ }^{1}$, PEDRO LEONARDO TALAVERA-IBARRA ${ }^{2}$, \\ KSENIA BOLOTINA ${ }^{1}$
}

\author{
${ }^{1}$ Peoples' Friendship University of Russia (RUDN University) \\ 6 Miklukho-Maklaya St., Moscow, 117198, Russian Federation \\ ${ }^{2}$ Missouri Southern State University \\ 950 Newman Rd., Joplin, MO 64801, USA
}

\begin{abstract}
This paper investigates the Basque toponymy in Canada, the USA, and Spanish speaking Latin America and determines various aspects of its static and dynamic. The authors examine and systematise the Basque toponymical heritages present on maps of the United States, Canada, and Spanish speaking Latin America, and propose a broader conception of Basque toponymy taking into account its dissemination beyond the original Basque residences. Approximately seventy place names cited in this article were selected due to their lingua-cultural, geographical, associative, and commemorative significance. Historical, linguistic, semiotic analysis and dialogic approach (introduced by M. Bakhtin), proposed in this research reveal Basque history and the Basque (Euskara) language's interactions with other languages and cultures reflected in New World place names. As modern studies (e.g., Loewen, Bakker, Igartua, Zabaltza) typically concern the Basque language's history, it is crucial to analyse the Basque influence on other languages and cultures and Basque toponymy based on the Euskara's linguistic contacts with the English, French and Spanish languages and corresponding cultures. For instance, calque toponyms, toponymical allusions, and anthropotoponyms that commemorate the Basques can be found in the toponymical heritages of the New World. Moreover, Basque place names in the New World feature a plane of expression that coincides with the lexical units underlying them, in addition to another plane that has been transformed through linguistic contact with dominant languages. Basque toponymical allusions can be explicit or implicit; in most cases, however, they are anthropotoponyms that can often be identified through Basque onomastic models of family names. Hence, the systematisation of Basque toponymy in the New World is an exciting and creative transdisciplinary undertaking for modern onomastics, general/applied linguistics, foreign languages teaching, as well as a stepping stone toward the creation of a typology that reflects diverse types of Basque onomastic heritages. The authors conclude that the New World Basque toponymy is a singular phenomenon in time and space.
\end{abstract}

Keywords: theoretical onomastics, toponymy, Basque language, Spanish language, English language, French language, topoformative elements, linguistic contacts, Basque toponymical allusion

\section{INTRODUCTION}

The interest in Basque toponymy is evident during classes in Spanish, English and French lexicology, Spanish and Latin American civilisations, USA and Canada civilisations, linguistic contacts investigations in toponomy. As the contemporary theoretical philology perceives the multinational languages as a set of parameters of divergence and convergence, we can approach place names of Spanish-speaking, French-speaking and English-speaking countries of the New World as markers of the perception of the universe by speakers of their different varieties. 
By investigating Basque toponymy from beyond the original places of Basque residence, the captivating historical evolution of the Basque language and its community is revealed. Nowadays, the Basque language (Euskara, Euskera) is an isolated language spoken by approximately one million people in the North-West of Spain and the SouthWest of France, and the most credible hypothesis about its origins ties the Basque language to the Aquitanian language (Igartua, Zabaltza 2012: 33). Basque namers left multiple place names conserved on their autochthonous territories. Nevertheless, the present Basque toponymy is not limited to the historical borders of its people and the modern Basqueland. On the contrary, it represents an extraordinary onomastic phenomenon in time and space.

Using the term 'The New World' (Mundus Novus) in its historical meaning as one of the names for the Western Hemisphere, we define the purpose of this research as to examine contemporary Basque toponymy of the New World, determine its frontiers, delineate its dissemination and establish its relevant features within the paradigm of time and space and a dialogue of languages and cultures.

To achieve our aim, the Basque place names throughout the New World chosen for their geographical, associative, and commemorative significance, are analysed on the basis of cartographic materials, lexicographical sources, a variety of texts and discourses. Also, the primary Basque toponymy is examined through the contacts of the Basque language with other languages and cultures, which left their mark on the Basque toponymy of the New World. The methodology for such a study includes the onomastic and discourse analysis as well as the lingua-cultural, semiotic analysis, dialogic approach and the survey of native speakers. This paper builds on our prior studies on the Basque place names (Chesnokova, Talavera-Ibarra 2016, Bolotina 2016, Chesnokova, Bolotina, Talavera-Ibarra 2017).

\section{THEORETICAL BASIS}

Place names reflect and catalogue space, and consequently, can be considered an onomastic reflection of the namers' model of the universe. The etymology and original meaning(s) of place names, as well as their motivation and morphological structure, are the traditional and constant object of toponymical studies. In newer semiotic studies of toponyms, their place among other systems of signs, as well as their three-dimensional interpretation, concerning semantic, syntactic, and pragmatic aspects, the three primary dimensions of any sign, is considered.

The place name lexicon is an inherent part of any language and, thus, uncovers a series of principles, which can be seen in the preservation of old toponymical roots as part of contemporary demonyms (Hispalense as a name for the inhabitants of Seville, Spain, mentioning the place name Hispalis, prior to Seville, which is used as a synonym to Sevillano), names of colors and numbers, and in anthropomorphic metaphors, for example. Once a name found, a principle of certainty is at work; we perceive the name as a part of a system since even a single place name can be explained through the systematic analysis of a series of place names.

The Basques have always been brave navigators, fishermen, sailors, whalers. Many Basques became famous as naval commanders and admirals (Caro Baroja 2004: 
124) and have contributed to the exploration and conquest of the New World since the first voyage of Christopher Columbus in 1492. That's why it is essential to establish diverse types of Basque onomastic heritages of the New World and to propose its typology on the basis of multidisciplinary paradigms. Cultural and onomastic analysis provides the backbone to the principal methodology used in this work. Such analysis combines the achievements of geography, history, onomastics, and traditional studies in dialectology, which can be aided by the semiotic approach, paying particular attention to the national toponymical lexicon and systems, their formation in the dialogue of languages and cultures, and their comparison.

The outstanding Russian linguist and philosopher M.M. Bakhtin stated in his work "The Aesthetics of Verbal Creativity" that in the interactions of cultures one culture puts questions to another one, and due to such issues, one culture opens its depths to another one (Bakhtin 1979: 283). A dialogical approach to Basque Toponomy of the New World focuses mainly on the Basque influence on Canadian, the USA, and Latin American place names' systems. It also shows some aspects which arise during the interaction of Basque culture in an anthropological sense of the word. Consequently, the dialogic approach to the New World Basque Toponymy derives both from linguistic and cultural factors and facilitates a complete description of Basque place names in a broader context.

\section{LINGUISTIC FEATURES OF BASQUE TOPONYMY IN THE ORIGINAL BASQUE RESIDENCES}

Basque toponymical landscape includes Hegoalde 'The South Country' and Iparralde 'The North Country', situated respectively in Spain and France and also known as País Vasco Español and País Vasco Francés. The South Country is made up of the Basque Autonomous Community (País Vasco; Euskadi, Basque: Euskal Autonomia Erkidegoa), the provinces of Álava (Araba), Guipúzcoa (Gipuzkoa), Vizcaya (Bizkaia), and the Autonomous Community of Navarra (Comunidad Foral de Navarra, Basque: Nafarroako Foru Erkidegoa). The North Country is part of France's Department 64, Pyrénées-Atlantiques (Basque: Pirinio Atlantikoak).

From ethnic and historic point of view, the Basque-speaking space is given the name of Euskal Herria or Vasconia. However, to name the entirety of the autochthonous Basque territories, Sabino Arana (1863-1903), known to be 'the Father of Basque Nationalism', proposed the term Euzkadi, which came to be accepted in the variant Euskadi in many types of modern Spanish discourse, for instance, in the mass media discourse, as a synonym for the Spanish autonomous region Basque Country (Pais Vasco): (1) "Podemos Euskadi ha reclamado hoy... la estrategia de pactos o la elaboración de candidaturas electorales en el ámbito del País Vasco, sin interferencias ni imposiciones ... El partido que dirige en Euskadi Roberto Uriarte ha querido así expresar su malestar ... en las tres provincias vascas" (Toña 2015).

It is critical to underline that Basque place names are common not only in historical Vasconia but outside Euskadi's territories as well. One particular explanation, for instance, links the presence of Basque names to the Reconquest in the Autonomous Community of Rioja (Agud 1973: 7). 
The Basque language stands aside in the genealogy of world languages. In the Iberian Peninsula, the Basque language is the only remaining language among languages dating before the advent of the Romance languages. The Basques themselves call their language Euskara (dialect variations: euskera, eskuara, and uskara), and they prefer to be known as euskaldunak, i.e. 'the people that speak Euskara'. Terms such as Basque, Vasco, and Vascuence have their origins in Latin. For Basque people, Euskara is a symbol of their national identity and a tool for the reconstruction of Basque history and the interpretation of Basque culture (Caro Baroja 2004: 236).

One of the greatest linguistic mysteries of our times, Euskara has given rise to multiple hypotheses about its onset. Along those lines, toponymical parallelisms have been established between the Basque and Armenian languages, for example (Sarkisian 2000). The most credible theory, however, ties the Basque language to the Aquitanian language, based on epigraphs from the first throughout the third century containing evidence of close to four hundred names of people and seventy names of deities (Igartua, Zabaltza, 2016, 33). Still the lexicon of the language as a topic of study has been rarely addressed. It has been possible to establish that the bulk of the Basque lexicon is made up of monosyllabic words, even if their etymology is not clear yet. As Igartua and Zabaltza state, about a half of the contemporary Basque lexicon has Latin origin (Igartua, Zabaltza 2016: 33).

The Basque toponymy as it is now came to be as the result of a dialogue between languages and cultures, an exchange that took place within the territories of the indigenous Basque settlings and with neighbouring regions, as well as their transfer to more distant locations. And this toponymy can be studied through the fixation method by uncovering its dialogic-associative links and its semiotic parameters in their three aspects: semantic, syntactic and pragmatic.

The agglutinative character of the Basque language results in the fact that in many geographical terms, we can explicitly set the topoformative elements. Many toponymy forming elements observed in modern Basque place names refer to landscape and nature (Caro Baroja 2004: 38), as the Basque language possesses a rich vocabulary for natural phenomena (Kurlansky 1999: 21). Also, the Basque place names of Spain refer mainly to proper personal names (Michelena 1989). We find the most significant number of native Basque names in the province of Guipuzcoa (Agud 1973: 39). For instance, the municipality of Zumarraga includes the root -zumar- ('elm') and the suffix -aga ('place'), which gives us the phytonymic version of 'place where the elms grow'.

The most productive topoformative elements are suffixes having the meaning of 'place' such as -ola and -oz(os) as well as roots -ibar-, -berri(barri)- and -uri- (Caro Baroja 2004: 38-40). The semantic content of 'place' is also expressed through the suffixes -eta, -aga, -doi (doki/dui/di). Here are some examples of place names with topoformants in question: Bañueta, 'place of baths'; Sagarminaga, 'place of bitter apples' and Sagardoqui, 'place of apples'; Urquiola, 'birch forest'; Zurriola, 'timber smithery'; Pagola, 'place of beech', Arratola, 'hut or smithy of passage', and Arrazola, 'place of broom'; Basauri, 'population in the forest', Uribarrena, 'the part of the city', Ochanduri, 'village of Otxando', Uriarte, 'between cities', Isauri, 'village of the ferns'. 
The origin of many of the Basque place names is still subject to debates. For this reason, Igartua and Zabaltza, authors of the "Brief History of Basque language”, emphasise the urgent need for an etymological dictionary of Basque language (Igartua, Zabaltza 2016: 25). Possible interpretations of the name Bilbao (Bilbo in Euskara), the administrative centre of the province of Vizcaya, show the controversial character the etymology of original Basque place names has. It is generally accepted that the name comes from the Latin bellum vadum 'beautiful ford' (Pospelov 1998: 68). However, according to studies by G. S. Sudar', based on ideas of the Spanish toponymist García Berlanga, the toponym Bilbao contains the formant bil 'small town' - a formant of high frequency in Basque-Iberian toponymy (Sudar' 2007: 115).

An essential feature of modern Basque toponymy in Spain is the existence of double, Basque and Spanish, names (Gernika - Guernica, Bilbo - Bilbao, Donostia San Sebastián), reflecting the centuries-old contacts of the Basque and Spanish languages. Double names are in the process of standardisation in the framework of state policy, and the unification of the literary standard Basque language (Euskara batua). Language consciousness of modern Basques preserves the original Basque toponymy as an essential part of national heritage, although in some cases the Spanish toponyms are preferred to the Basque ones (Bilbao, not Bilbo, for example).

\section{BASQUE TOPONYMICAL HERITAGES IN CANADA}

\subsection{English speaking Canada}

The Basques have always been referred to as seasoned fishermen. One of the specialities of Basque cuisine is cod. Euskara counts of many dialectal names for cod (Kurlansky 1999: 59), likewise there are many hybrid place names that refer to cod in English-speaking provinces of Canada. Here are few of them: Baccaro Point in southwestern Nova Scotia; Baccallieiu Island, off the north of the Avalon Peninsula; two small islands called Baccalhao (Rayburn 2001: 108).

A. Rayburn speaks of about three hundred different toponyms of Basque origin in Newfoundland and the Gulf of St. Lawrence (Rayburn 2001: 196). According to A.I. Il'ina, place names of Basque origin prove varying degrees of assimilation in such English-speaking provinces of Canada as Newfoundland and Labrador (Il'ina 2013: $106-110)$.

\subsection{Quebec}

The Basques were one of the first European nations to play the seas of Nord Atlantic near the island of Newfoundland looking for the best places for cod fishing and whaling. However, fishing couldn't be the only reason for Basque expeditions. The fact that many territories along St. Lawrence estuary bear witness of Basque presence (Egaña Goya 1995) justifies this statement.

Quebec researcher Brad Loewen (Loewen 2016), having analysed the etymology of the ethnonym Iroquois, agrees with Charles Martijn (Martijn 1990) on the assertion that the Basques had some kind of 'privileged relationship' with the Iroquois. How could 
one come to such a conclusion by studying the origin of the name? As Danish linguist Peter Bakker (Bakker 1989, 1991), who B. Loewen (Loewen 2016) refers to, states in his research, certain names of Native peoples, adapted by French colonists at the turn of the XVII century, have Basque origin. In particular, all the ethnonyms ending in -quois are French assimilation of demonyms featuring a productive Basque suffix $-k o+a$ which means 'the people of'.

The idea of the close relationship existing between the Basques and Iroquois, the relationship that possibly thwarted French explorer Jacques Cartier's plans to build a colony in the New World and ended for a certain period of time French expeditions, is supported by the fact that "all the Native groups involved in the Wabanaki schism $<\ldots$..> already had Basque names by the time the French encountered them. These names show a precise knowledge of Native groups, their territories, what they called themselves, and possibly their political history. ... all [names] follow Basque linguistic rules, indicating they were coined by Basque speakers who had direct knowledge of these groups before French got to know them" (Loewen 2016: 60 - 61).

Basque presence on the present-day territory of the province of Quebec was noticed by a French explorer, founder of Quebec City, Samuel de Champlain (Champlain 1613, 1632). According to the Canadian researcher and journalist Alan Rayburn, the gulf Chafaud aux Basques owes its name to the encounter of Samuel de Champlain and some Basque fishermen dehydrating fish on a wooden scaffold (fr. échafaud) (Rayburn 2001: 110). Among other explicit toponymical allusions Lac du Basque, Île aux Basques, Anse aux Basques, Rivière du Basque are worth mentioning. All these place names designate different areas on the opposite sides of the St. Lawrence River.

The cited examples reflect the Basque presence on the territory of Quebec before and during the French colonisation. However, these place names are not of Basque origin. Among those toponyms that have Basque etymology, we can state all the place names featuring Orignal 'moose' (Orignac, Orignaux). As it is stated in the Loanwords dictionary, the etymology of this word ascends to the Basque word oregnac (Tardivel 1991: 253). More than 200 place names in Quebec honour this majestic animal, inhabiting the forests near St. Lawrence River.

Some researchers see Basque etymology in the place name Gaspé. Quebec toponymist Jean Poirier (Poirier 2006 XXXVI), as well as the Basque researcher L. Michelena, attributes Basque origin to the name of the city tracing it to the Basque word gerizpe, kerizpe (shelter). M. Egaña Goya agrees with the statement, mentioning the introduction of the place name Caispe on the map of the Basque explorer Piarres Detcheverry in 1677 (Egaña Goya 1995).

According to the Basque journalist Xabier Harluxet, among other place names of Basque origin in Quebec, one should take into account the name Barachois (Harluxet 2003). In his opinion, the Basques originally used the word barachois to denote small basins by the side of St. Lawrence River, where the fishing boats were anchored.

It is toponymy of Basque origin as well as French, English, and Amerindian which is widely spread in Quebec. This fact develops the idea on the Basque toponymy in time and space. 


\section{BASQUE TOPONYMICAL HERITAGES IN THE USA}

Basque place names in the USA, as in other territories once constituting New Spain, record the successful efforts of Basque colonists. Since Southwestern and Central States of America were parts of the Spanish Empire, Basque missionaries and explorers visited the area.

For instance, Basque missionaries, Franciscan friars, played a crucial role in the exploration of California, as it is well shown in John O'Hagan's book “When the Basques Ruled California 1784-1834" (O'Hagan 2015). Place names commemorating Basque missionaries are not rare in the toponymy of the region. To cite a few, they are Point Lasuen and Point Fermin (Firmin on some maps) - places named in honour of Padre Fermín de Lasuén, a Basque, the founder of a number of Franciscan missions in California (Gudde 2004: 130, 205).

Examples of Basque toponyms in California are numerous. Mostly, they are anthropotoponyms. Such place names as Aigare, Sopiago Creek, Yparraguirre Canyon come from Basques surnames.

Names of some of the most prominent figures in exploring New World are commemorated in Californian place names. Anza, Anza-Borrego Desert State Park, Lake Anza, Anza Valley are named for Juan Bautista Anza, a leader of a famous expedition. Bolivar Lookout commemorates South American revolutionary leader of Basque descent, Símon Bolivar. Interesting is an example of a place name Arlanza, which is a combination of a toponym Arlington and an anthropotoponym Anza.

Basque personalities played a significant part in creating American place names. Such names as Cupertino, Mission Dolores, Escondido (Escondida), Lake Merced, Natividad Valley/Creek, San Fernando are the names introduced by Anza expedition and are first mentioned in Anza's diaries.

Basques received lands as payment for their services of seafaring and exploring territories. Hence, many places bear names of Basque ranchers, sheepherders, and landowners. As in Agoura, Agureberry Point, Amesti, Leonis, Mendico, Rambaud Peak.

Even though among American place names of Basque origin commemorative anthropotoponyms are dominant, there are few other toponymical allusions to cite. As, for example, transfer name of Navarro, CA, is an allusion to the Spanish Province Navarra (Gudde 2004: 257).

Basques' presence is the most notable in the state of California. Still, they have left an imprint on the toponymical worldview of various states of America. To cite a few more examples of Basque legacy in the USA, they are the community place name Arriola, CO, an anthropotoponym, referring to a Basque last name (Bensone 1994: 10) and Durango, CO. The Basque connection is obvious, when it comes to the place name Durango, whether in Colorado, Texas, or Iowa, as it derives from Durango, Bizkaia.

St. Ignace, MI, as St. Xavier, MT, honours the Basques saints - Saint Ignatus of Loiola and Saint Francis Xabier respectively.

Presented material is not a complete list of place names of Basque origin in the USA. Still, the selection reveals the role Basques played in the exploration of the territories consisting the modern United States. Being instrumental in the discovery, they formed groups of colonising settlers in different regions of America, creating the BasqueAmerican legacy. 


\section{BASQUE TOPONYMICAL HERITAGES IN LATIN AMERICA}

Remarkable is Basque toponymical influence on the toponymy of Latin America. Beginning with the fact that Basques were many members of Columbus expedition, many Latin American Presidents have had Basque surnames (Salaberri 2011).

Contemporary Latin Americans in response to the question 'what place names in their countries have Basque etymology' usually identify them by Basque surnames, a phenomenon corresponding to anthropotoponyms.

As far as the Latin American Presidents' toponymical legacy is concerned, the family name Bolivar, of Simon Bolivar (Simón José Antonio de la Santísima Trinidad Bolívar de la Concepción y Ponte Palacios y Blanco; 1783-1830), eminent military leader, fighting for independence of Spanish colonies in Latin America, national hero of Colombia, Venezuela, Ecuador, Panama, Bolivia and Peru, is widely represented in the national toponymy of many Latin American countries. For the countries cited above Simon Bolivar is El Libertador 'The Liberator', El Padre de la Patria 'The Father of The Motherland'.

According to Salaberri, Basque last name Bolivar comes from Bolibar (Salaberri 2011: 146). The official name of Venezuela - Bolivarian Republic of Venezuela (República Bolivariana de Venezuela) — perpetuates the memory of Simon Bolivar (Simón Bolívar).

Colombia is divided into thirty-two departments. The name of the department of Bolivar, founded in 1905, memorialises the surname of the famous hero of Latin America.

There are about fifteen place names Bolivar in Latin America. Apart from being the name of the department in Colombia, Bolivar is the name of a province in Ecuador, state in Venezuela, as well as oiconyms in Argentina (province of Buenos Aires), Bolivia (department of Beni, department of La Paz), Colombia (Department of Antioquia, Department of Valle del Cauca, Department of Cauca, Department of Santander), Peru (Department of Libertad), Uruguay (Department of Canelones).

Basque and Spanish colonists, as it is widespread among shift names and calque toponyms, gave Basque place names to new lands.

Here are some of many examples: the city of Laredo situated in Cantabria, bordering the Basque Country, has Basque etymology — ' good field'. The name of Laredo functioning as calque place name can be seen on the map of the USA and Mexico, in the states of Texas and Tamaulipas respectively.

There are three cities in Mexico duplicating the name of the capital of Vizcaya, i.e. Basque toponym Bilbao.

Mexico City is one of the most significant urban agglomeration of the world. It is divided into colonies. Colonies of Narvarte and Echegaray in the Mexican capital and some of its prospects such as Echegaray, Juan Sánchez Azcona, Concepción Beistegui are of Basque origin.

The famous Mexican supermarket chain is called Bodegas Aurrera ('forward' in Basque).

Basques have played a significant role in the development of Colombian Antioquia and the formation of the Antioquia's ethnic type known as paisa. The department of 
Antioquia counts of numerous examples of Basque anthropotoponyms which spelling coincide with Basque surnames and thus they are identified by them. For example, Puerto Berrio. Berrio is the paternal surname of a Colombian lawyer, military, and politician, Don Pedro Justo Berrío. His patronym is immortalised in the name of the port of Puerto Berrio, the central square of Medellin, in the name of the city park, synonymous to is corazón de Medellín 'the heart of Medellin'. The same name is found in many urbanonyms: the name of the railway station, the main street and the park in Santa Rosa de Osos which happens to be Pedro Berrio's birthplace.

Basques played a unique role in the history of Chile. Basque onomastic heritages are perceived in Chilean urban place names. In the modern Santiago, the capital of the Republic of Chile, there are, for instance, Plaza Gernika 'the square Gernika', calle Bilbao 'Bilbao Street', duplicating original Basque place names Gernika, Bilbao, respectively.

One of the famous Chilean vineyards has a name of Basque origin, Eyzaguirre, which is a family name of emigrants from Vizcaya, Spain, who founded the Vino de Eyzaguirre in Colchagua Valley, renowned for the perfect climate for growing grapes.

Chilean oronym Euzkadi is a calque of Sabino Arana's neologism. Here is an example from media discourse to explain nomination means: (2) "Una cita y otra conducen estas líneas hacia las faldas del cerro Euskadi, una mole de 3.615 metros que existe bautizado en el país andino desde tiempos de la Guerra civil española y que son contadas las personas en el mundo que saben de su ser. Vizcainos exiliados en Chile le dieron tal nombre -en un comienzo prohibido- con el fin de dedicarle la cumbre a su patria y a la llegada al enclave americano del lehendakari José Antonio Aguirre" (Trinidad 2014). To a degree, as it is proper for Chilean toponomy on the whole, the article Lo is combined with some Basque elements: Lo Elizondo.

Argentina being an exceptional example shows the historical presence of Basques on its territories (Zorroguieta 2012). Let us point out that Buenos Aires was founded by Juan de Garay (1528 - 1583), a Basque from Orduña or Biscay (Basque Country). The south part of Buenos Aires, finds an avenue named after Juan de Garay: La Avenida Juan de Garay. Modern Buenos Aires is divided into barrios 'quarters'. One of the quarters bears name of Barrio Villa Ortuzar. This place name is an anthropotoponym immortalising the surname of Santiago de Ortuzar. In 1862, a native from Vizcaya, Santiago de Ortuzar moved to Argentina and bought the land that gave birth to the current name of the quarter.

Amidst other Latin American anthropotoponyms, referring to Basques, it's worth to mention the city of Lascano which is situated in the Department of Rocha, northeastern part of Uruguay. It was named after a Basque explorer and seafarer Francisco de Lascano.

The Republic of Paraguay is a mostly bilingual country, with the official status of Spanish and Guarani, the indigenous language of the Tupian family. Place names Zeballos cué, Zeballos cué are identified by Basque surnames and are notorious by archaic Guarani topoformative cué (modern kue) meaning 'which belonged to'. In the Republic of Paraguay, there are many interesting examples of commemorative anthropotoponyms, memorialising Basques. Iturbe, a town in the Guairá Department, received its name in honour of Vicente Ignacio Iturbe (1786-1837), Paraguay national hero, of Basque origin. 
Latin American Basque onomastic heritages represent a flexible and developing phenomenon in the present socio-cultural context. To commemorate the tragic bombing of Basque town of Gernika (April, 26, 1937), reflected in Pablo Picasso's famous antiwar painting Guernika (1937), several locations in Latin America received its name in addition to numerous calque toponyms (González-Allende 2016: 151—152) in both Basque (Gernika) and Spanish (Guernica) versions of the original name of the town Gernika (Euskara) - Guernica (Spanish version) in the province of Biscay.

\section{BASQUE PLACE NAMES IN FOREIGN LANGUAGE TEACHING}

Basque toponymical commentaries in courses on Spanish, French and English lexicology, Spanish, French and English dialectology, semiotics, culture-oriented linguistics, New World civilisation, and the theory and practice of translation achieve the aim of multiculturalism of modern languages teaching.

Place names per se represent particularly interesting sites to explore individuals' discursive work. Basque toponymical commentaries can be students' research on the etymology of toponyms of Basque origin, the results of their assimilation by the dominant language. In case of anthropotoponyms, special commentaries on their protagonists and their significance for the history are welcome. Attention to toponymical commentaries contributes to the creative dialogue between the Basque and other cultures, as well as to the dialogue between the national cultures of the Spanish, French and English speaking world.

\section{CONCLUSION}

New World Basque toponymy casts light on the history of the Basque people and the current state of Euskara considering the contacts of languages and cultures.

The concept of Basque toponymy appears as a broad spatial and temporal model. Basque calque toponyms in the toponymy of the New World, toponymical allusions and anthropotoponyms that commemorate the Basques, have both a plane of expression coinciding with lexical units motivating them and a plane of expression that has been transformed due to linguistic contacts with the dominant language.

Basque toponymical allusions can be either explicit or implicit. In most cases, they are anthropotoponyms, identified by Basque onomastic models of family names, mostly.

Systematization of the Basque toponymy outside the original area of Basque residence is an exciting and creative task of modern onomastics, theoretical and applied linguistics. Basque place names are an inherent part of orientation not only in original Basque geographical space but also in New World geographical and cultural space. A broader concept of Basque place name studies proposed in this paper reveals various aspects of their statics and dynamics, enriches the understanding of their lingvocreative manifestations and aesthetics, and becomes an effective tool in teaching foreign languages at Bachelor and Masters levels, contributing to students' intellectual activities and plurilingual identities.

(C) Olga Chesnokova, Pedro Leonardo Talavera-Ibarra, Ksenia Bolotina, 2018 


\section{REFERENCES}

Agud, Manuel (1973). Areas toponimicas en el País Vasco [Toponymical areas in the Basque Country (In Spanish)]. ASJU 7. 37-56. Retrieved from: http://www.ehu.es/ojs/index.php/asju. [Last viewed 09.09.17].

Bakker, Peter (1989). 'The language of the Coast Tribes is Half Basque': A Basque-Amerindian Pidgin in Use between Europeans and Native Americans in North America, ca. 1540 - ca. 1640. Anthropological Linguistics, 31, 117-147.

Bakker, Peter (1991). A Basque etymology for the Amerindian tribal name Iroquois. Annuario del Seminario de Filologia Vasca (ASJU Geh), 14 (2). Bizkaia: Universidad del País Vasco, $1119-1124$.

Bakhtin, Mikhail (1979). Aesthetics of Verbal Creativity. Moscow: Iskusstvo. (In Russ.)

Bensone, Maxine (1994). 1001 Colorado place names. Illustrations by Robin Richards. Lawrence, KS: University Press of Kansas.

Bolotina, Ksenia (2016). Quebec toponymy: linguistic-culturological analysis. Philological Sciences. Issues of Theory and Practice 2016. № 11. Part 3, 74-77.

Caro Baroja, Julio (2004). The Basques. Translated from Spanish. Moscow: URSS. (In Russ.)

Chesnokova, Olga, Talavera-Ibarra, Pedro Leonardo (2016). El diálogo de lenguas y culturas en la toponimia vasca. Ibero-American studies, 2(12). Moscow: MGIMO University, 72-76.

Chesnokova, Olga, Bolotina, Ksenia, Talavera-Ibarra, Pedro Leonardo (2017), Basque toponymy in the New World. Acta Onomastica, 1/LVIII/2017, 53-62.

de Champlain, Samuel. (1613), (1632). Les voyages du sieur de Champlain Xaintongeois, capitaine ordinaire pour le roy, en la marine... Paris, éditions de 1613 et 1632.

Egaña Goya, M. (1995). Les toponymes basques au Québec. Le Naturaliste Canadien. Hiver 1995. QC: Les Editions l'Ardoise, 54-57.

González-Allende, Iker (coord.). (2016). El exilio vasco: estudios en homenaje al profesor José Angel Ascunce Arrieta. Madrid: Ediciones Deusto.

Gudde, Erwin G. (2004). California Place Names. Berkeley: University of California Press.

Harluxet, Xabier. (2003). La langue basque et quelques traces des basques au Quebec! Retrieved from: http://www.euskonews.com/0198zbk/kosmo19802fr.html. [Last viewed: 01.06.17].

Igartua, Ivan, Zabaltza, Xabier. (2016). Breve historia de la lengua vasca.Donostia-San Sebastián: Instituto Vasco Etxeparre. Retrieved from: www.etxepareinstitutua.net. [Last viewed: 26.08.17].

Il'ina, Anna. (2013). Inhomogeneity of toponymical naming units of English speaking Canada as an image of Canadian linguistic world view. Ph.D. thesis. (In Russ.).

Kurlansky, Mark. (1999). The Basque History of the World. New York: Penguin Group.

Loewen, Brad (2016). Interwined Enigmas: Basques and Saint Lawrence Iroquoians in the Sixteenth Century. Contact in the $16^{\text {th }}$ century. Networks among Fishers, Foragers and Farmers. Edited by: Brad Loewen, Claude Chapdelaine. Mercury Series. Ottawa: University of Ottawa Press, $57-75$.

Martijn, Charles A. (1990). The Iroquoian Presence in the Estuary and Gulf of St. Lawrence River Valley: A Reevaluation. Man in the Northeast 40. Rindge, N.H.: Anthropological Research Center of Northern New England, 45-63.

Michelena, Luis (1989). Apellidos vascos. San Sebastian: Cuarta edición.

O'Hagan, John (2015). When the Basques Ruled California 1784-1834. Caldwell, Idaho: Caxton Press.

Poirier, Jean (2006). La toponymie du Québec. Dictionnaire illustré - Noms et lieux du Québec. Quebec: LES PUBLICATIONS DU QUÉBEC. XXXIII-XLV. 
Pospelov, Evgeniy (1998). Geograficheskie nazvaniya stran mira: Toponimicheskiy slovar': Svyshe 5000 edinits. [Geographic names of world's countries: Toponymical dictionary: More than 5000 naming units. Moscow: AST. (In Russ.)].

Rayburn, A. (2001). Naming Canada. Toronto: University of Toronto Press.

Salaberri, Patxi, Salaberri Iker (2011). Basque Legacy in the New World: on the Surnames of Latin American Presidents - ASJU, xlv-2. Bizkaia: Universidad del País Vasco, 115-151.

Sarkisian, Vahan (2000). Vascos y armenios: Documentos y materiales. Erevan: Asoghik.

Sudar', Galina (2007). Ispanskaya toponimiya [Spanish toponymy]. Moscow: RosNOU. (In Russ.).

Tardivel, Louis (1991). Répertoire des emprunts du français aux langues étrangères. Quebec: Septentrion.

Toña, Miguel (2015). Las listas de Podemos Euskadi abren una brecha con la dirección nacional, El País, 15 de noviembre de 2015. EDICIONES EL PAÍS S.L. Retrieved from: https://elpais.com/ccaa/2015/11/04/paisvasco/1446654187_649430.html [Last viewed: 15.09.17].

Trinidad, Víctor (2014). Repetí el ascenso al cerro Euskadi para subir a su cima una ikurriña comprada en Durango. About Basque Country. Retrieved from: https://aboutbasquecountry.eus/2014/09/09/lacima-vasca-mas-alta-tiene-3-615-metros-de-altura-y-esta-en-los-andes/ [Last viewed: 20.08.17].

Zorroguieta, Jorge, Goyenechea, Mauricio (2012). Los vascos en la Argentina: familias y protagonismo. Anuario de la Fundación Vasco Argentina "Juan de Garay”. Buenos Aires.

\section{Article history:}

Received: 20 November 2017

Revised: 15 December 2017

Accepted: 15 January 2018

\section{For citation:}

Chesnokova, Olga, Pedro Leonardo Talavera-Ibarra, and Ksenia Bolotina (2018). New World Basque Toponymy in the Dialogue of Languages and Cultures. Russian Journal of Linguistics, 22 (2), 251-264. doi: 10.22363/2312-9182-2018-22-2-251-264.

\section{Bionotes:}

OLGA S. CHESNOKOVA is Full Professor at the Department of Foreign Languages at RUDN University. He has authored more than 190 publications on diversity in the Spanish language, intercultural communication, linguistic contact, Spanish-Russian-English translation, and toponymy. Altogether, 12 students have defended their $\mathrm{PhD}$ dissertations under her supervision, six on Toponymy in Latin America, Canada, and the USA. Contact information: e-mail: tchesnokova_olga@mail.ru

PEDRO LEONARDO TALAVERA-IBARRA is PhD in Comparative Literature (UT, Austin Texas, USA), full-time Professor at the Department of Foreign Languages of Missouri Southern State University, USA. He is a specialist on Spanish and Latin American civilizations, the author of 40 publications and original methodologies of teaching Spanish, and has more than 30 years of teaching and research experience in Mexico and the USA. Contact information: e-mail: Talavera-P@mssu.edu

KSENIA BOLOTINA is PhD student completing her Doctoral dissertation and is devoted to the onomastics of Quebec, Canada and Quebec ethno specific discourse. She is the winner of the best postgraduate student award (Master of Linguistics) - 2015, awardee of the government scholarship for scientific research 2016-2018, and is a current participant of full employment PhD program at RUDN University. Contact information: k.e.bolotina@gmail.com 


\title{
БАСКСКАЯ ТОПОНИМИЯ НОВОГО СВЕТА В ДИАЛОГЕ ЯЗЫКОВ И КУЛЬТУР
}

\author{
О.С. ЧЕСНОКОВА ${ }^{1}$, ПЕДРО ЛЕОНАРДО ТАЛАВЕРА-ИБАРА ${ }^{2}$, \\ К.Э. БОЛОТИНА ${ }^{1}$ \\ ${ }^{1}$ Российский университет дружбы народов \\ 117198, Москва, ул. Миклухо-Маклая, д. 6 \\ ${ }^{2}$ Южный Университет Штата Миссури \\ 950 Newman Rd., Joplin, MO 64801, USA
}

В статье обобщаются результаты исследования баскской топонимии Канады, США и испаноговорящих стран Латинской Америки; в статике и динамике определяются ее экстра- и интралингвистические параметры. Авторы анализируют и систематизируют баскское топонимическое наследие, представленное на картах Канады, Соединенных Штатов Америки и испаноговорящих стран Латинской Америки, и предлагают широкое понимание баскской топонимии, принимая во внимание ее распространение за пределами ареала исконного проживания басков. Примерно 70 упомянутых и проанализированных в статье топонимов было отобрано на основании их лингвокультурной, географической, ассоциативной и коммеморативной значимости. Исторический, лингвистический, семиотический и диалогический (по М.М. Бахтину) подходы, использованные в исследовании, раскрывают особенности баскской истории, а также взаимодействие баскского языка (Euskara) с другими языками и культурами, что нашло отражение в топонимии Нового Света. В связи с тем что современные исследования баскского языка (см. Loewen, Bakker, Igartua, Zabaltza) в основном сосредоточиваются на его истории, авторам представилось важным изучить баскское топонимическое влияние на другие языки и культуры, а также рассмотреть баскскую топонимию через призму языковых контактов баскского языка с английским, французским и испанским языками и соответствующими лингвокультурами Нового Света. Топонимы-кальки, топонимические аллюзии и коммеморативные антропотопонимы, воздающие дань баскам, являются частью топонимического наследия Нового Света. Установлено, что план выражения баскских топонимов Нового Света соответствует лексическим единицам, используемым для обозначения соответствующих географических объектов, а план содержания подвергся изменениям ввиду языковых контактов с доминантным языком. Баскские топонимические аллюзии могут быть как эксплицитными, так и имплицитными; в большинстве случаев это антропотопонимы, баскская этимология которых прослеживается через типичные для баскских фамилий ономастические модели. Таким образом, систематизация баскской топонимии Нового Света является трансдисциплинарной задачей современной ономастики, романогерманского языкознания, общей и прикладной лингвистики, теории и методики преподавания иностранных языков, а также важным шагом на пути к созданию типологии, отражающей разные типы баскского ономастического наследия. В заключение авторы приходят к выводу, что баскская топонимия Нового Света является уникальным явлением в парадигме времени и пространства.

Ключевые слова: теоретическая ономастика, топонимия, баскский язык, испанский язык, французский язык, английский язык, топоформанты, языковые контакты, баскские топонимические аллюзии

\section{История статьи:}

Дата поступления в редакцию: 20 November 2017

Дата принятия к печати: 15 January 2018

\section{Для цитирования:}

Chesnokova, Olga, Pedro Leonardo Talavera-Ibarra, and Ksenia Bolotina (2018). New World Basque Toponymy in the Dialogue of Languages and Cultures. Russian Journal of Linguistics, 22 (2), 251-264. doi: 10.22363/2312-9182-2018-22-2-251-264. 


\section{Сведения об авторах:}

ОЛЬГА СТАНИСЛАВОВНА ЧЕСНОКОВА - доктор филологических наук, профессор, профессор кафедры иностранных языков филологического факультета Российского университета дружбы народов, автор более 190 публикаций по варьированию испанского языка, межкультурной коммуникации, языковым контактам, переводу художественного текста в парадигме русский-испанский-английский языки, топонимике Латинской Америки. Под ее руководством были защищены 12 диссертаций на соискание ученой степени кандидата филологических наук, 6 из них - по топонимии Латинской Америки, Канады и США. Контактная информация: e-mail: tchesnokova_olga@mail.ru

ПЕДРО ЛЕОНАРДО ТАЛАВЕРА-ИБАРРА - профессор кафедры иностранных языков Южного Университета Штата Миссури (США). Защитил диссертацию по сравнительному литературоведению в Техасском университете в Остине (США). Автор более 40 публикаций, создатель авторских методик по дистанционному преподаванию испанского и русского языков, имеет более 30 лет опыта преподавательской и научно-исследовательской деятельности в Мексике и США. Сфера научных интересов: цивилизация Испании и Латинской Америки, русская, испанская, французская и латиноамериканская литература, русский и французский символизм, поэзия модернизма. Контактная информациия: e-mail: Talavera-P@mssu.edu

КСЕНИЯ ЭДУАРДОВНА БОЛОТИНА - аспирант кафедры иностранных языков филологического факультета Российского университета дружбы народов, победитель конкурса лучший выпускник (2015 г.), участник программы «Аспирантура полного дня» (инновационная программа РУДН, направленная на развитие академической карьеры и вовлечение аспирантов в мировое научное сообщество, 2016-2017 гг.), стипендиат правительства РФ (20162018 гг.). Сфера научных интересов: ономастика и этноспецифический дискурс Квебека, Канада. Контактная информация: k.e.bolotina@gmail.com 